IDEA - Studia nad strukturą i rozwojem pojęć filozoficznych $\mathrm{XXIX/1}$ Białystok 2017

\author{
Valentine Ehichioya Obinyan, \\ Albert Osemeamhen Onobhayedo
}

(Benin, Nigeria)

\title{
GLOBALIZATION AND CULTURE MODIFICATION: RESHAPING THE INSTRUMENTS OF SOCIALIZATION TOWARDS AFRICAN SOCIETAL DEVELOPMENT
}

\section{Introduction}

Many scholars engaged in the globalization discourse and have made valuable contributions to our understanding of the subject. One of these is Dukor who has argued in his; Globalization and social change in Africa that globalization is a "light or ray beaming from one end to a galaxy of uninformed, unmoved, worlds. Yet, it is a philosophy of a village of nations and homosapiens, starting from somewhere but to nowhere because it is a philosophy of change for an interconnected network of a people in the universe" (Dukor, 2008:16). Thus, he saw globalization as both a cognitive and an instructive human process in which ancient African participated, noting that the first phase of globalization is the ancient phase when the urge and prompting to communicate economically and culturally was more intrinsic than necessary in man within the spectrum of his world or universe.

Ashni and Jando noted that turning the world around through the process of globalization originally, cannot be accurately pinged to a time and personality. (2008:50) But according to them, as an economic, political, social and cultural reality, globalization as a process of unification could be traced back to the month of May of the year 34 B.C., when Alexander the Great (336-232), 
a Macedonian war lord, instigated the project of unifying the Macedonian and the Persian Kingdoms into one people (Vidler, 1981:10). Along with his great army, he set out the decimation of Greek language, culture and way of life in the nook and cranny of the earth. Influenced "by vastly more mundane motives: (Bright, 1981:412) and moving "in part by the Pan-Hellenic ideas" that Greek culture was superior to all others, a tradition he inherited from Aristotle his teacher, Alexander consolidated his new global village. Thus, this marked the birth of Western Europe's influence on globalization. After this, globalization took other forms and dimensions. From the 1800s the focus of globalization which took the form of colonialism in Africa had the intention, predominantly, of economic exploitation, acculturation and political domination. This period according to Uzoiqwe, in his: 'European Partitioning and Conquest of Africa', marked the scramble and partition of over 28 million square kilometre of African continent. Africa, in the face of globalization, was conquered and effectively occupied by the industrialized nations of Europe. (Uzoiqwe 1990:10)

Reflecting on the present global existential predicaments, it is only natural to note that globalization can only be true to its goal of promoting free trade and securing world peace when it begins to create more winners than losers in the global economy. The role of the multinationals in the global economy is such that, "in the early 1990s it was estimated that about 37,000 Multi-National Companies (MNCs) worldwide controlled assets in two or more countries and that these corporations were responsible for marketing roughly 90 percent of the developed countries' trade", especially in Africa. (Sachs, 1999:137). Has this changed in recent time? Does Africa contribute anything to the global market? Does it still maintain the position of a helpless receiver? The argument is: can Africa's participation in globalization go beyond mere buying of finished goods from the West? With the cosmetics of cultural pluralism, multiculturalism and cross culturalism, in fact 'global villagization', is African 'culturing' still available for the family, for children, for communication, for education, for religion and for self-projection? If globalization infers transformation and transformation infers development, then how is Africa captured in the present domino of globalization. Who is globalizing the process? Seeking answers to these questions is the interest of this paper. But first, let us clarify some concepts. 


\section{Conceptual clarification}

\subsection{Culture}

Many definitions have been given of culture from various dimensions such as law, dressing, songs and even proverb but most fundamental is the unifying factor of the various dimensions - language. However, etymologically, the word culture is a derivative of the Latin word cultus, meaning a way of doing things, ways of acting, among given people (Ejim, 2006:18). From its German derivative, culture is from the word kutu' translated literarily to mean civilization. From action to civilization, therefore, culture circumference a complex ways a people act and live, shared by every member of the social group or community and transferred from one generation to the next. Culture therefore is a complex phenomenon having many forces and element within it. According to Schaefer, "culture is the totality of learned, socially transmitted customs, knowledge, material object and behavior. It includes the ideas, values, customs and artifacts of groups of people..." (Schaefer, 2005:58).

For Norbeck (1970:5) culture is an abstraction from reality and not reality itself; that is, culture prescribes why, how and where people should gain a decent livelihood. Swartz and Jordan (1980:47) toeing the same line, view culture as shared understanding of norms, rules or laws that govern and control behavior, belief in religion, superstition, witchcraft, myths, and ideology.

It is evident from our definitions of culture that;

I. It is ideational, it resides in the mind of men, manifesting in behaviors of the people.

II. It is a phenomenon that is shared by all.

III.It is learned directly or indirectly and communicated through language and other symbols.

IV.It is universal yet it is minimized to certain group of people. On this note, culture is the instrument of adoption; it contains ideas and techniques for responding to challenges of human experience.

The above views are also shared by Malinoswki (1974:77). For him, culture facilitates the gratification of basic human needs such as food, shelter, water and sexuality. Howard and Mekin (1983:14) emphasize the normative value of culture in the area of law, social structure and religion. From the above 
understanding, culture transforms the individual, social institution and the society. It is not wrong to say, then, that culture is instrumental to development of a people, their institution and their society hence the survival of any culture is dependent on the solidarity or the bound of unity between the members and the extent to which this bond directs and shapes their view of the world and those around them.

Generally, a culture performs two roles in the society, namely;

\section{a. Adaptive Role.}

Trade (1988:27) asserts that adaptive role can be seen as the principal equipment through which men and women in the society cope and interact with their material environment, which is interwoven with social and economic development. Culture shapes to a large extent the mechanism of providing basic and other needs in a society.

\section{b. Integrative Role.}

Through integrative roles, culture is significant in the creation of a moral community within any defined society. Culture provides the bonds and symbols for the existence of peoples within communities and for the reproduction of individuals and personalities equipped to effectively play useful and relevant role in their societies. Cabral (1970:66) sees culture as a dynamic element of the society.

\subsection{Globalization}

Although one of globalisation's most primitive motives is to create an interrelation and interconnection which will reduce the world to one 'global village' or a 'global parlour' irrespective of the several miles or space, differences in race, colour or tongue, separating its continents. By this, the world is expected to share a harmonized, unified, transparent and healthy economic structure as well as cultural and social virtues. However, there is no consensus on the definition and utility of the concept. (Dukor, 2008:50)

Various scholars have examined the concept from different perspectives, especially from political, social and economic angles. More recently, it has been skeptically viewed as one phase of political and economic neocolonialism ${ }^{2}$ (ibid) as its propagative tools are enculturation and acculturation, but for the sake of this study, we shall adopt Dukor's definition of the concept as contained in his; 'Globalization and African Identity', where he opined that: 
Globalization is a process by which the network of cultural, political and economic advantages and interest of the different peoples of the world naturalistically for mutual benefits. It is expected the ...the identities of different races and peoples of the world... would merge, clash and conflict to the disaster of global peace and unity irrespective of the contributions of science and technology to the advancement of the standard of life generally on the planet ${ }^{3}$.(Ibid)

Strictly analyzing the above definition, one can deduce that Maduabuchi's idea of a network of political, cultural, economic and maybe religious advantages accrue to the races of homo-sapiens (Negroid, Caucasoid, Mangoloid) to the extent that it blurs colour, class, ethnic and sectarian differentiation In the same token is expected to foster lasting peace, unity, love and harmony through a human-centric globalization. We also have these shades of the concept; Cultural Globalization- Information Globalization- Political Globalization and Economic Globalization.

\section{Globalization, culture and development: the web, implication and challenges}

The subject matter of globalization is "integration" and this is one of the dimensions in the working of the global system. It is a process, so to speak, that aims at the integration of cultural systems through the exchange of sociocultural values, belief-systems and ideas. The natural consequence is that globalization as a process towards unity of cultural systems, by its nature, makes for "increased choices" - varieties. This is in fact true to the essence of globalization which has its unveiling, disclosing and unfolding in variety. The argument is that the world can be a lotus paradise where billion of varieties blossom and true pathway to peace and progress is conceivable only in that freedom and blossoming of the varieties. This idea agrees with the declaration of the Governments to the States Parties in the opening pages of the Manual of General Conference of UNESCO (2002):

That ignorance of each other's ways and lives has been a common cause [of world wars, poverty, underdevelopment], throughout the history of mankind, of that 
suspicion and mistrust between the peoples of the world through which their differences have all too often broken into war (2002:7).

The whole idea is that wars, poverty and ignorance are natural consequences of our inability to have a holistic picture of the world. Every part of the world has some uniqueness to offer either in cash or kind, to make the world more and more a lotus paradise. Thus, it is glaring that globalization has its roots in the idea of beauty, freedom, equality, human dignity, mutual respect for human beings and peace. The mindset to discover, explore, taste of what other countries have to offer, set the way straight for industrialization of the world. The spirit of the process facilitated the speedy discoveries of oil, diamond, gold, and other natural resources in various parts of Africa. The discoveries in Africa and Middle-east paradoxically, bred competition - a trend that negates the very spirit of collectivity and togetherness. Indeed, United States has proved her 'superiority' in a number of ways in trade, technology and military capability. And this idea of superiority in modern times remains a cardinal issue in globalization. This is because it has brought about a form of conceptualization of globalization that equates it with a vile and sinister form of internationalization. The challenges in this web of communication and internationalization, has attracted certain philosophical conceptualization and critique of the globalization process. These critiques include;
a. Globalization as Materialism.
b. Globalization as Darwinism
c. Globalization as Monism
d. Globalization as Naturalism
e. Globalization as Consumerism etc

This interpretation of globalization as neo-imperialism presents globalization as a paradox of itself. This is the paradox where one civilization makes all attempts to impose their values on others; negating the fact that globalization is a collective effort of all nations, tribes, cultures and individuals that have values. It is paradoxical because globalization as a process has it point of departure from its goal to 'villagize' a world where varieties blossom and create an atmosphere which is welcoming to all and not the other way round where one cultural system blossoms at the expense of others. In this regard, 
Africa seems to be a victim of such cultural domination and this, perhaps, accounts for why Africa is grossly undermined in the emerging global structure. Could this be what affects Africa's development?

\subsection{Glbalization and african social institutions}

From the foregoing, it is clear that globalization is not new to the Africans precisely because of the traditional systems and mode of operation as well as discoveries of natural resources. Though Africa has a long history of interaction with the rest of the world, especially through North Africa, the most significant phases, in terms of reach, are those of the era of merchantilism, slave trade, colonial rule and extant inter-state relations. Contact with Europe and America in the 15th century through trade and colonial rule opened the way to the modern trend. However, it gave rise to the sordid experience in slave trade and exploitation. In the trans-Atlantic slave trade, western merchants bought from African slave traders, Africa's most valuable resources - able-bodied men, women and children. This has impaired Africa's stability and development. Colonialism compounded the situation through its calamitous and dehumanizing exploitation and instrumentalization which has snowballed into mental slavery. The world with its highly technologized globalization process is simply dragging Africa along as a dependant. This can be explained through two metaphysical constructs;

a. Globalization through colonization, - Affecting its social systems, such as the family, social, political and economic institutions.

b. Globalization through de-mentalization - Dehydrating its selfconfidence and reconstructing its psych.

Analogically, this aligns with the notion of 'civilized poverty' or a 'poverty of the civilized'. In jumping into what has become conventional, Africans have shelved several sublime practices and are even substituting crass individualism for the much cherished African hospitality. We must bear in mind that our interest here is the globalization of cultures as it affects societal development in contemporary Africa.

In Africa, globalization was a 'hope ship' expected to sail Africa across the waters of existential predicament as well as a compensation for the inhumanism of colonialism. The process, supposedly, will help developing 
countries especially Africa "create better economic environments", jump into the information age, accelerate development and enhance global harmony while still upholding the pristine values of their cultural heritage. But has this taken place? Is it taking place? Will it take place? When?

Consequent upon the erosion some sublime African values, African scholars especially philosophers regard globalization with skepticism and even with great concern about the future of Africa. George Ekwuru (1999) calls it "the "de-culturisation" and "de-personalization" of a people within their own land'. In the historical moment of colonialism, through the process of forced acculturation, western civilization came heavily on the African cultural world bringing about a battering and shattering experience and an irreparable cultural trauma. This accounts for the enduring, debilitating psychic effect which has crystalised in the terrible nightmare of inferiority complex.

Various institutions such as churches working in Africa, including the Catholic Church, have been worried. The Holy See published a note on finance and development, immediately before the United Nations Conference in Doha, which states:

We need to pay particular attention to Africa, where the development map shows strong inequalities. In Africa, the situation is different from country to country; there is a trend towards polarization between situations of success in obtaining resources and making them fruitful, and situations of total marginalization.

To make this case, that is, the erosion of African culture through globalization, more vivid, let us give some practical illustrations. Africa, particularly sub-Saharan Africa, has been culturally bastardized. Since encounter with colonialism, African countries have not been able to articulate the charting of their history, economy, culture and identity to ensure her development. Reflecting on this dilemma, a former Nigerian Director of the National Council of Art and Culture averred;

Our attitude today is largely influenced by the perception and the view- points cultivated as a result of slavery as well as colonial and post-colonial education. As a result of this, we tend not to appreciate ourselves or our cultures and therefore disregard or undervalue the potential contributions this effort can make to our 
contemporary developmental efforts. We thus tend not to believe and have confidence in ourselves our endemic capabilities and potentialities. (Bello, 1998:12emphasis added by Maduagwu)

The fallout of a hyper individualism, capitalism and materialism in the western world is transmitted all over the world as the modus operandi which Africans try to assimilate. This assimilation, paradoxically, enables and disables the instrument of societal development in many unanticipated ways. Let us consider them in sequence.

\subsubsection{Globalization and the African Family}

Our pristine valued communal life is fast disappearing. The extended family system which aided communication and cares for members of the family including the poor, orphans and widows in a network of interrelatedness has atrophied. As the sense of community disappears, the individual loses his or her true identity, value, dignity and meaning and is vulnerable to abandonment, dependency, corruption and discrimination. Hence according to Aldous Huxley, the incredibly high rate of divorce in societies all over the world is symptomatic of the general deterioration in wholesome human relationships and 'divine' institute of marriage and family hood. One is indeed very sure that in a very short time values like; marriage, virginity, or even child birth, will be mockery as they will be parameters for determining being 'civilized' and 'uncivilized'. No wonder, having felt the implication of the dearth of communication within families and worse still, within extended family, Asa in her lyric; 'Fire on the Mountain' asks;

There is fire on the mountain and no body seem to be on the run, there is fire on the mountain top, and no one is running ... Who is responsible for what we teach our children, is it the internet or the stars on the television why o why, why o why... There is fire in Africa, everywhere in the sea and nobody seem to be on the run, there is fire, fire, and no is a running.

Reconciling this dilemma of every one for him-self with our positive cultural value of brotherhood is a challenge for the present African. 


\subsubsection{Globalization and Religion in Africa}

Religion permeates African life and has been an instrument in social development. From time immemorial, African traditional religion is endowed with salient values, instrumental to the development of individuals and societies, providing solace for adherent and meeting their spiritual and psychological needs. But upon contact with the white man, things changed Basden captures this clearly when he noted;

The downright truth is that the Europeans find it difficult to fathom the native mind. They are generally ignorant of the essential spiritual element which will equip them to unravel the intricacies of the native mind and their ancient law and custom. (Basden, 1966:5)

This is a pointer to the superfluous ignorance and a display of superiority complex on the part of Europeans and the West in general. Many Africans accepted Christianity and began to regard traditional worship as fetish, barbaric and primitive. It is still debatable as to whether they were convinced or brain washed. Besides, these two religious systems now functions in the African continent but their essences is been assailed by new global socio-economic forces and the result is hollow religiosity of both the Christians and traditional worshipers. We are beginning to have a brand of spirituality without morality and good conscience.

In this scenario, most African communities have become infested with certain curious activities such as; spurious miracles, unacknowledged syncretism, mammon worship and sectarian violence. Sectarian violence, save with interference of Islam was hardly a challenge in Pre-colonial Africa. The existing sets saw themselves as partners in progress and alternative routes to spiritual wellbeing. Cross-set worship was permitted and enriched the spiritual experience of the people. There was even a cross-community acceptance of deities, For instance most of the deities such as Orunmila, Sango and Ogun worshipped in the ancient Benin Kingdom were of Yoruba origin. Benin Olokun worship also percolated into Yorubaland. Thus, the African had attained a culture of tolerance in this regard, which is in line with the spirit of globalisation. This explains the relative ease with which Christianity spread. Until the element force was introduced by Islamic jihadists religious proselytisation was relatively carried out peacefully. 
Conversely, religious intolerance pervades inter-set relations in this era of globalisation. Islam and Christianity, apart from denigrating traditional African religion as primitive and damned are also poised to suppress each order. Taking advantage of the flexible, tolerant and open attitude of Africans in religious matters, they have foraged deeply into Africa to gain a wider sphere of influence. However, the reverse is not the case. Save for the fragments of traditional African religion that African slaves took the Americas, African ways of worship have not significantly plied globalization as a highway to other cultures. Even, well cherished values like African hospitality and extended family support mechanism have not been globalized. Therefore, the inflow of cultural influence completely outweighs the outflow of African ideas on a global scale.

\subsubsection{Globalization and Education (School) in Africa}

Education was not an alien contraption in pre-colonial Africa. It predated foreign incursion into the continent and served as an instrument of social engineering. It was a socio-spiritual experience which harboured elements of social etiquette and morality. Moral codes were woven into sayings, parables and stories and dispensed orally. Thus we all remember the concept of the tales by moon light and the picture of children sitting at the foot of an old story teller. Like the ancient African Egyptian philosopher affirmed, listening and hearing is an important tool for attitude development that could translate into social development. This whole pattern of teaching was prevalent in the whole Africa. In fact it was our traditional means of educating the young. This to a large extent enabled respect for the old, for knowledge and for parents. People who have good character and knowledge of basic essential family, self and societal values were considered educated.

Since the colonial era, this whole pattern has changed. Fluency in English language is mistaken for intelligence and civilization. Ability to speak and write in the colonial master's language is taken for being educated. Formal education has became a passport for gaining prestige, hence competition for places in higher education translate into competition for prestige. The local languages became outmoded and displaced. According Obioha:

Colonialism eroded the place of African languages in African economies by granting the highest prestige value to school education in colonial languages. 
Colonial languages were valued over and above African languages. Consequently, educational qualification in an African language became of less value than qualification in the colonial language. (Obioha 2010:6)

Human, cultural and material developments have become feasible only when they are pursued in the colonial language. Whereas traditional education addressed all three elements, colonial education was designed to alienate the African from his or her culture. Ultimately, it encouraged dependence and stifled creativity. Colonial education emphasised literary and technical education and acquisition of skills, competition for jobs as against character formation. Rivalry and inordinate competition for jobs has given rise to moral depravity which has soared in contemporary Africa. There is a collapse in family values, high corruption in public life and hyper-materialism among educated Africans both in government, religious and business circles. This trend is exacerbated by the extant phase of globalization which is further opening Africa up to the influence of practices like pornography, lesbianism that were not condoned in traditional education. It is now hard to find places, even in the rural areas, were chastity and virginity before marriage is celebrated. Africans lament the gradual passing away of these heritages.

\subsubsection{Globalization and the Africa Youth}

The developmental impact of globalisation on the youths cannot be over emphasized. (Schlegel, 2001) They have enough maturity and autonomy to pursue information and experiences outside the confines of their families. They are easily influenced largely because they are not yet committed to a definite way of life and their habits, belief and behaviour have not ossified (Arnett, 2002). Thus they are vulnerable to the influence of global media and the internet. Research has shown that vices such as substance abuse and premarital sex and unwanted pregnancy are on the increase as a result of the intrusion of Western values through globalisation of information and communication technology. This view was canvassed by scholars like; Nsamenang, 2000; Stevenson, \& Zusho, 2002; Welti, 2000; Nnedum, 2003. Adolescent identity is an important issue in globalisation discourse as well as in adolescent development (Arnett, 2002; Nnedum, 2003).

In African, physical communication is being fast replaced by the use of electronic and digital gadgets, leading to complacency or indifference to 
communal and family inter-personal relations. This has stultified the sense of brotherhood hitherto enjoyed in the traditional setting.

Furthermore, African communities are drained of available manpower as young people migrate to urban areas and to places outside Africa in search of work. Consequently, many have developed a multi-cultural identity, with global consciousness (Nnedum, 2003). Today, most young people have developed a global identity and are immersed in a global culture. The television and social media have assisted this transformation process because they exposure African people to events and information from all over the world (Arnett, 2002:777). The internet has become the strongest component of the media for it provides a platform for direct communication with other people worldwide, via e-mail, interactive games and chat rooms such as Facebook, Instagram, WhatsApp (Nnedum, 2003). Also it provides direct access to information about every part of the world). It is, therefore, apt to believe that the images, values, and opportunities they perceived as being part of the global community undermine their belief, values and cultural practices (Arnett, 2002). Crime in Africa has also assumed a more sophisticated dimension with the introduction of cyber fraud. Advanced fee fraud has become a pastime of many young men who seek to gratify their appetites for the tantalising things the internet has exposed them to. One could argue, therefore, that the internet has exacerbated the identity crisis experienced by young Africans since the colonial era. (Erikson, 1950, 1968) Their hybrid identity has become stronger than ever.

Again Arnett (2000) observes that one of the glaring changes promoted by globalisation is evident in the timing of transitions to adult roles, such as work, marriage, and parenthood. It has been noted that the global economy is highly technological and information based, which means that the amount of education required to prepare young people for jobs is stretching steadily longer (Arnett, 2002). Unlike the pre-colonial times, when the teens and early 20s were considered adequate, young people who have come under the influence of Western culture tend to wait longer to go into marriage and parenthood, (Arnett, 2000). This is considered expedient in medical sciences but it has taken its toll on decency, chastity and moral rectitude that are cherished pre-marital life in Africa. Relatively early marriage definitely reduced promiscuity. This is of little moment today. What is emphasised is a longer period of tutelage, acquisition of Western education in line with western culture. But how do these changes fit into the social development of Africa? 
The negative effects of globalization are definitely more conspicuous among the youths. Oni (2005:2) observes that Nigerian youths are rapidly losing touch with cultural values and that this could be seen in the alien culture which they portray; their bizarre dressing, dancing and language which invariably affect other aspects of social life. This is not peculiar to Nigerian youths. Nicolaides (2012:123) made a similar observation about South African youths. He states as follows: The younger generation of teenagers in south Africa have for the most part abandoned their African culture and language, and often religion and try to be hip by imitating their American rap artist role models who for most part display an acute lack of values and act immorally on television shows and who promote promiscuous behavior especially in the lyrics of the music they write. Youths are supposed to promote our culture and at the same time help to transmit it from one generation to the other. Therefore, it is deplorable when they fail to play this role.

As Bello and Adesemoye (2012):

...teenagers and youths generally are vital segments of the society who could be instrumental in promoting African cultures. But unfortunately, the mentality and lifestyle of the teenagers in African societies have been grossly affected by exposure to western films to some extent that rather than promoting African cultures, they have become hardened acolytes and promoters of western culture.

In what follows, globalization has not been true to its original goal of encouraging cross fertilisation of ideas in the world. It seems hijacked by the West and her allies to dominate the world and impregnate it in with their values. If this unwholesome cultural hegemony is not checked, and credible balance restored, the world will suffer a 'cultural meltdown', loss of varieties and eventual human underdevelopment.

\section{Towards african social development}

From the aforementioned, it is crystal clear that this paper categorically affirms that at the heart of African degenerative social life is cultural dependence. Africa indeed needs a cultural renaissance. The contact of the Africans with the west through colonialism and globalization as argued above 
has its negative implications than benefits. Most importantly, African cherished values and virtues are fast eroding. Usually, in a balanced wheel of cultural evolution, when two cultures contact, a gradual process of mutual cultural borrowing takes place, consciously or unconsciously. The two cultures interrelate and trans-valuate essences. But when one is backed by a stronger economy and fire power, there will be cultural domination and cultural chauvinism. Acculturation made possible by cultural inter-relativism is indeed most cherished as it leads to cultural diffusion and development Cultural imposition occasion a paradigm shift of indigenous cultures from their unique pattern of organization. It could result in the extinction of a disadvantaged pattern, however lofty. This is currently the experience in African where some indigenous languages are under threat of extinction.

Cultural confusion in contemporary African could be regarded as one of the causes of African underdevelopment and the reasons are not farfetched: Culture-capture as a phenomenon is socio-psychologically rooted. It breeds dependence syndrome and halts creativity. This leads to low productivity and poverty in a viscous circle that has become the lot of African states. Globalisation has hounded Africans into the positions of receivers of products of other people's creativity and weak participants in global affairs. Africa largely gratifies its immediate needs through purchases but finds it difficult to create sophisticated gadgets with global appeal. Globalisation ensures that western products are always accessible, producing a false sense of development in Africa. Thus, the existing mechanism of globalization derives from the economic and political calculations of the West. Africa has remained a back-bencher, dragged along by the major powers, waiting for crumbs from global politics and the global economy.

Africa needs to re-appraise its position, in the face of the exploitation, limitations and pretentions of globalization. It must also re-evaluate its concept of development which is problematically influenced by Western models today. The position of the cultural milieu in African development must be redefined with a view of re-integrating valuable African cultural practices into the matrix of globalization: This is the position of this paper. The paper submits that development is holistic (not only economic and political) and should address the psychological, spiritual, social and components which globalization tend to trample upon. 
For Engelbert Mveng, "the reconstruction of Africa must first start with regaining the spirituality empirically rooted in African cultural values". But how can Africa meet her unique and pristine cultural values that have been corrupted by westernization? It is an expectation that the desired change will be engendered by a law which should reflect an ethics of responsibility at all levels of the society. When this is done, globalization will become a less damaging experience in African. To facilitate the reshaping of African experience in globalization, the following steps may help.

1. Africans must discard the inferiority complex that make them believe that what is foreign is automatically better and realize that culture-wise, Africa has a lot that is superior and therefore admired by other peoples. In this, Academic bodies, orientation agencies such as the National Orientation Agency (NOA) of Nigeria and African movie industries, religious bodies as well as association for the preservation of cultural heritage have a lot to offer.

2. The target of Africans should not be to retain their cultural practices raw and unprocessed. Change, which is the law of nature, must be accommodated for culture to be adapted to changing circumstances. They should direct the process of cultural evolution to make it relevant to Africa's peculiar developmental needs.

3. In view of the critical role the instruments of socialization plays in national development, African leaders should be conscious of the fact that there is an insidious global culture competition going on which negates the quest for national development. They must articulate and respond with a grand strategy to be anchored on good governance, competence in science and technology, literacy and cultural renaissance.

4. Africans should curb the predatory tendencies of the West to ensure, balance of opportunities and investment, through appropriate legislation.

5. Promote legal competence in order to be able to deal with the dynamics of international law which the developed countries utilize in manipulating the trajectories of globalization in their favour. African states should ply the web of inter-state dealings encouraged by globalization to seek the repatriation of money stolen by their leaders and stashed away foreign banks.

6. Institute policies to protect sublime African cultural practices from trans-national Non-Governmental Organisations, that often canvass values and models that may not suite Africans' idea of societal development. 
7. improve on the educational system to reduce the high level of illiteracy and build up human capacity to compete with others.

8. African states must improve on their policies, infrastructure, technology, standards and protect local industries to enhance competitiveness and efficiency.

\section{Conclusion}

The Manual of General Conference of UNESCO (2002) states that:

1. That ignorance of each other's ways and lives has been a common cause, throughout the history of mankind, of that suspicion and mistrust between the peoples of the world through which their differences have all too often broken into war. (2002:7)

2. That the great and terrible war which has now ended was a war made possible by the denial of the democratic principles, of the dignity, equality and mutual respect of men, and by the propagation, in their place, through ignorance and prejudice. (2002:7)

This UNESCO's observations have only pinpointed the pathway to peace and development. It projects the need for synergy between states and men of all cultures. This implies respect for all cultures and a civilized, de-racialised approach to evaluating the effect of cultural patterns on people. Such understanding will lace the matrix of globalization with varieties and tolerance. Ultimately conflict will be minimized. We must understand that this approach is not the case of a man with a wipe or a sword or a gun bending all cultures but one that is fair, procedural, systematic and fundamentally ontological.

The scope of conflict in the world today transcends wars. The NorthSouth divide between developed and developing countries, unfavourable balance of influence, brain-drain, infringement on national sovereignty, made worse by globalization, affect Africa negatively andare potential sources of conflict.

According to Wiredu, these "kind of reverse injures human dignity and sap self-confidence... In Africa colonialism has been such an adversity" (Wiredu, Problems in Africa's Self-Definition 59, 60-69). Rechanneling this cause is still the interest of this paper. The adverse effects of colonial mentality modernized through globalization make it difficult for the African to be himself and as such, he acts in ways that are alien to his culture. The reality of a 'global village' is 
such that one section of humanity comfortably amasses the wealth while the other wallows in under-development. "Structural Adjustment Programmes" induced by the World Bank and International Monetary Fund and adopted by many African countries including Nigeria are facilitated by the principle of globalization. In effect, they have made the Affected African states like Nigeria more dependent. The masses wallow in poverty, African primary products are cheaper in the international market and multinational companies dominate the economy.

It is the position of this paper that Africans should learn from the views canvassed by some sages: John Dewey, the American philosopher, has warned that "a culture which permits science to destroy traditional values, but which distrusts its power to create new ones is destroying itself. (Dubos, 1971:432) Alvin Toffler told the world in 1971 that "the horrifying truth is that, so far as much technology is concerned, no one is in charge". (Toffler, 1971:432) Africans should therfore realize that is an open field in which they have a stake.

Jean-Marie Domenach says that the human being we see on the street today is falling apart submerged by affluence and slotted into a machine universe, the human being feels himself or herself becoming a thing among other things and begins to be afraid and feel unnecessary. This means there is a need to temper the machine orientation which is fast creeping into Africa with elements of humanism, which derives mainly from culture. (Domenach, 1973:24) Rene Dubos observation reinforces this position. He opined that humanity is on a suicidal course. He says that the most poignant problem of modern life is the feeling that life has lost significance, dignity, value, meaning and purpose. He further analyzed that:

In many respects, modem man is like a wild animal spending its life in a zoo; like the animal, he is fed abundantly and protected from inclemency's but deprived of the natural stimuli essential for many functions of his body and his mind. Man is alienated not only from other men, not only from nature, but more importantly from the deepest layers of his fundamental self. (Dubos, Ibid)

These account for the reason Pascal Blaise warned that man must realize he is not like other things in the world so as not to be soaked in it and become like them (Blaise). But this attitude regrettably, is the mode of operation of almost every man in our world today and especially the African who away from 
the community now stands for himself in a Darwinian existence. What Africans should seek is a human-centric globalization to address this bundle of paradoxes between man, capital and development within the context of globalisation.

Efforts to protect local culture from the homogenizing effects of globalization, many have encouraged the formation of organizations and groups at the local, national, and international level that aim to promote the protection of traditional cultures. World Cultural Organization suggested by Jeremy Rifkin (Rifkin, 2001) is helping to represent diverse cultures and put cultural protection on an equal footing, alongside International Network for Cultural Diversity. (INCD, 2003) which proposed that:

1. Governments must not enter into any agreements that constrain sublime local cultures and the policies that support them.

2. A new international agreement should be created, which can provide a permanent legal foundation for cultural diversity.

The objectives of INCP's include: developing an international approach to cultural issues, protecting cultures endangered by globalization, and raising awareness of the importance of culture (INCP, 2012). The INCP is an international forum through which representatives of member countries can exchange views on emerging cultural policy issues. One of the ways in which the INCP seeks to strengthen cultures is by advocating more cultural exceptions to the global trade rules of the WTO. Forty-five countries are members of the INCP, including Canada, France, China, and the United Kingdom, but not the United States. We must state that cultural protectionism is of great necessity now and African states should embrace it.

Finally in this global process, the responsibility of developing Africa holistically is every African's task. Just as we noted at the beginning, African culture which has been significantly eroded by centuries of slavery, colonialism, and imperialism by Euro-American agents is at risk of total extinction owing to the pace of globalisation. This has given rise to the call for revitalization. Revitalization should be done with the realization that culture is the soul of any society. 


\section{Summary}

Twenty-first century scholarship is replete with studies on the effect of globalization on indigenous culture in less developed countries. Such studies have accorded the African world ample space because globalization has fostered epochal changes in Africa's cultural terrain. Though more subtle in recent times, in comparison to the hegemonic tendencies of the colonial past, it has created monumental changes in the social, economic, political and spiritual life of African groups. Notably absent, notwithstanding, are theories to explain the extinction of values and quest to recover pristine African cultural life which globalization has remodeled. Thus, this study seeks a philosophical insight into the historical realities, trajectories and impact of globalization in Africa. It captures what many regard as African existential predicament. It shows the character of globalization in relation to Africa, drawing attention to the objectives, actors, gainers, and losers of the process. To ensure this, this research reflects on certain fundamental questions such as; what is globalization? What are its objectives? What is the role of globalization in the formation of cultural identity? How are the West and its allies captured in the process? What is culture? Where is the African family, the African child and African religion in globalization? The basic interest of this study is to epistemologically establish that globalization has had corrosive effect on African culture, which is tantamount to distorting the vital force that could facilitate African development.

Key words: globalization, culture, value, African society, developments

\section{Bibliography}

Akande W (2002). The Drawback of Cultural Globalization. Yellowtimes. Bell D (1993). Communitarianism and its Critics. Oxford: Clavedon Press.

Akindele, S. T. (2002). et ali. - "Globalisation, its implications and consequences for Africa" In. http:// globalization.icaap.org/content/v2.1/01_akindele_etal.html

António Ramalho Eanes (2009), in INTERNATIONAL CONFERENCE Africa E Globalization: Learning from the Past, Enabling a Better Future. Engelbert Mveng was murdered at home near Yaoundé (Cameroon). He was a Jesuit priest and left a considerable work as historian, theologian, poet and sculptor.

Asa \{ashs\}, (2007) in Her lyric's, Track 5, "Fire on the Mountain" by Lyke De Don Entertainment, Lagos.

Ashni, M. W. and Jando, F. (2008), "Preserving African Identity in the global process", in Globalization and African identity in M. Duko's (ed) Essence interdisciplinary-international Journal, 5 .

Austin Flannery (1975) ed., "Gaudum et Spes", in Vatican II: The Concilia and post Concilia documents, Boston.

Bangbose, J. A. ,(2008), "Globalization As An Impediment On The African Culture", in Globalization and African identity in M. Dukor's (ed) Essence interdisciplinary-international Journal, 5.

Bello, S (2010) Communication and Cultural Promotion for Sustainable Development: The Challenges of Globalization. In Semiu Musa Bello and Adesemoye (2012) "Western Films 
and Teenagers in Nigerian Societies: The Question of Cultural Promotion.” Continental journal of Arts and Humanities 4(2).

Benedict XVI, Encyclical Caritas in Veritate. In http://www.vatican.va/holy_father/benedict_ xvi/encyclicals/documents/hf_ben-xvi_enc_20090629_caritas-in-veritate_po.html

Bentley, J. H. (2008). "Traditions and Encounters: "A Global perspective on the Past", Microsoft ${ }^{\circledR}$ Encarta ${ }^{\circledR} 2009$ (DVD). Redmond, WA: Microsoft Corporation, (12/7/2011).

Boahen, ed. General History of African VII: Africa Under Colonial Domination 1880-1985 (UNESCO: James Curry.

Bright, (1981), J. A. History of Isreal” Third 3ed (Philadelphia: West Ministers Press.

Domenach, J. (1973) "The Attack on Humanism in Contemporary Culture", Concilium.

Dukor, M. (2008), "Globalization and African Identity" in Essence interdisciplinary-international Journal, 5 .

Dukor, M. (2008), "Globalization and Social Change", in Globalization and Africanidentity in M. Dukor's (ed) Essence indisciplinary-international Journal, 5.

Ehusani, G.O. (1991), An Afro-Christian Vision 'Ozovebi': Towards A More Humanized World, Lanham: New York, University Press of America Inc., (find also R. Dubos, 1973, p. 22 A. Huxley, p. 16).

Ejim, J.O. (2006) "An Introduction to the Study of Religions" in Oyoade E.O, ed. Readings in Religions and Philosophy, Teredial Technian Enterprise, Benin City.

Fisher, S. (2001) "The Challenge Of Globalization in Africa". A Pepper Presented At the International Monetary Fund Conference at the France-African Summit (Yaounde Cameroon Jenuary 19.

Fromm, E. (1976), To Have or To Be, New York: Abacus.

Grandoni, D. (2012, March 9). On the unlikely viral success of 'Kony 2012'. The Atlantic \Wire. Retrieved June 24, 2012, from http://www.theatlanticwire.com/technology/2012/03/unlikelyviral-success-kony-2012/49730/

Holmes H. and Sorensen, G. (1995), whose world Order? Uneven Globalization and the End of Cold War', (Colorado: Westview Press,

Huxley, A. (1965), Brave New World Revisited, New York: Heinemann Education Books.

Ikoku, E. A. (1976), African Development with a Human Face, London (Eng): African Books.

Kenny p. (1989) The Rise and Fall of the Great Powers, New York: Vintage Books.

Kungua, (2009) Benoît Awazi Mbambi - Le Dieu crucifi é en Afrique.

McMicheal, P. (2000), "Myth and Realities". In J.T. Roberts and A. Hite, (Eds). From Modernization to Globalization a Perpective on Development and Social Change, C/U.S.A.: Blackwell publishers.

Mohammed Sokoto A. (2006) "Globalization and Cultural Pluralism: Consequence and Challenges for Africa”. In Fullbright Alumni Nigeria Bok of readings,No. 1 Globalization and National Development in Nigeria.edited by Maduagwu Micheal O and Onu V., National Institute Press, Kuru(others in this journal are; The Phenomenon of Globalization and the Afrtican Response, Globalization and its Influence on African Culture: A Discourse on the Conquence.

Nicolaides A (2012) "Globalization and Americanization- The Hijacking of Indigenous African culture." Global Advanced Research Journal of History, Political Science and International Relations, 1(6). 
Obioha Uwaezuoke Precious (2010) Globalization and the future of African culture in Philosophical Papers and Reviews Vol. 2(1), pp. 1-8, April 2010 Available online at http://www.academicjournals.org/PPR (C) 2010 Academic Journals.

Ogugua (2007) Culture and Development, in Philosophy and Africa vol., 1. Amawbia: Lumos Nig. Ltd.

Ogunbanjo, B. (2001), "Globalization and African Dilemma”, in Humaninties Review Journal, i.

Ogunbanjo, B., (2001), "Globalization and the African Delimma" in Humanities review Journal Vol. 1, No. 1.

Oni, Adesoji A (2005) "Globalization and Its Implication on African Culture and Development: Challenges for Education”. International Journal of African and African American Studies 4(2).

Pontifi cal Council for Justice and Peace - Note of the Holy See on fi nance and development on the eve of the United Nations General Assembly Conference in Doha (18 November 2008). Reprinted with permission. pp.19-20.

Pope John XXIII, (1961), Mater et Magisteria, New Light on Social Problems, London: Catholic truth Society, pp. 69-161.

Rifkin, J. (2001, July 3) Worlds apart. The Guardian.

Tabb, W.K. (2008). "Globalization". Microsoft ${ }^{\circledR} 2009$ Ensarta ${ }^{\circledR} 2009$ (DVD). Redmond, WA: Microsoft Corporation, (12/7/2011)

Toffler, A. (1971) Future Shock, New York: Bantam Books.

Toye, E. (1999), "Dollar Imperialism as Globalization”, The Guardian, Monday 29 and The Guardian, Tuesday, $30^{\text {th }}$, March, p. 40.

Uzoiqwe, G. N. (1990), "European Partitioning and Conquest of Africa", in A.A.

Vidler, A. R. (1981), The Church In An Age Of Revolution, (Middle Sex: Penguin Books.

Wolfgang Sachs, (1999) Planet Dialectics: Exploration in Environment and Development, London: Biddle Ltd., Guildford and Kings's Lynn,

Zaato, M.K. (2008) "Cultural Identity Of The Minority Ethnic Groups In Nigeria In The Face Of Globalization" in Globalization and African identity, M. Dukor's (ed) in Essence interdisciplinary-international Journal, 5.

Valentine Ehichioya Obinyan, Ph.D

Department of Philosophy and Religions, faculty of Arts, University of Benin, Benin City. Nigeria.

\section{Albert Osemeamhen Onobhayedo}

Department of History and International Studies, University of Benin, Benin City. 